\title{
FAKTOR-FAKTOR YANG MEMPENGARUHI KINERJA PEGAWAI LEMBAGA PENYIAR PUBLIK TVRI STASIUN NTT
}

\author{
Simon Sia Niha ${ }^{1}$, Henny A. Manafe ${ }^{2}$, David Manafe ${ }^{3}$ \\ 1,2,3 Fakultas Ekonomi dan Bisnis, Program Studi Magister Manajemen, Universitas Katolik Widya Mandira Kupang \\ Jl. Jend Achmad Yani No.50-52, Merdeka, Kupang, NTT 85211 \\ 1'ss.mukin11@gmail.com, ${ }^{2}$ hennyunwira@gmail.com, ${ }^{3}$ davidmanafe96@gmail.com
}

\begin{abstract}
ABSTRAK
Penelitian ini bertujuan untuk menganalisis pengaruh teknologi informasi, lingkungan kerja, motivasi kerja, organizational citizenship behavior atau OCB, dukungan sosial terhadap kinerja pegawai yang dimoderasi oleh dukungan sosial di Lembaga Penyiaran Publik TVRI. Penelitian ini berjenis survey kuantitatif. Populasi dan sampel dalam penelitian ini berjumlah 61 orang. Data yang digunakan berjenis data primer dan sekunder. Pengumpulan data melalui wawancara, kuesioner dan dokumentasi. Teknik analisis data menggunakan teknik analisis statistik deskriptif dan analisis statistik inferensial. Hasil analisis statistik inferensial menunjukkan teknologi informasi memiliki pengaruh yang signifikan terhadap kinerja pegawai, lingkungan kerja tidak berpengaruh signifikan terhadap kinerja pegawai, motivasi kerja berpengaruh signifikan terhadap kinerja pegawai dan OCB tidak berpengaruh signifikan terhadap kinerja pegawai. Untuk hasil uji moderasi menunjukan bahwa dukungan sosial mampu memoderasi teknologi informasi terhadap kinerja pegawai, dukungan sosial tidak memoderasi pengaruh lingkungan kerja terhadap kinerja pegawai, dukungan sosial memoderasi pengaruh motivasi terhadap kinerja pegawai dan dukungan sosial memoderasi pengaruh OCB terhadap kinerja pegawai. Kata Kunci: Teknologi, Lingkungan, Motivasi, OCB, Kinerja
\end{abstract}

\section{ABSTRACT}

This research aims to analyze the effect of information technology, work environment, work motivation, OCB, and social support on employee performance moderated by social support at the TVRI Public Broadcasting Institute. This research uses a quantitative survey. The population and sample in this research consists of 61 people. The data used are primary and secondary data. Data collection methods of this research are interviews, questionnaires and documentation. The data are analyzed using descriptive statistical analysis techniques and inferential statistical analysis. The results of the inferential statistical analysis shows that information technology has a significant effect on employee performance, the work environment has no significant effect on employee performance, work motivation has a significant effect on employee performance and OCB has no significant effect on employee performance. The results of the moderation test shows that social support is able to moderate information technology on employee performance, social support does not moderate the effect of the work environment on employee performance, social support moderates the effect of motivation on employee performance and social support moderates the effect of $O C B$ on employee performance.

Keywords: Technology, Environment, Motivation, OCB, Performance

\section{PENDAHULUAN}

Manusia merupakan sumber daya yang penting dalam sebuah organisasi atau perusahaan, karena manusia atau karyawan atau pegawai merupakan modal utama suatu organisasi yang memiliki peran penting dalam mencapai tujuan sebuah organisasi. Tujuan organisasi atau perusahaan dapat tercapai, apabila pegawainya memiliki kinerja yang maksimum. Kinerja karyawan perlu dinilai oleh pimpinan agar dapat diketahui sampai sejauh mana kinerja dari seorang karyawan pada khususnya dan organisasi pada umumnya. Kinerja menjadi sebuah ukuran bagi keberhasilan organisasi. Pencapaian yang baik dari sebuah organisasi ditentukan oleh hasil kerja pegawainya.

Lembaga Penyiaran Publik TVRI atau biasa disingkat LPP TVRI sangat diperlukan karena Indonesia merupakan negara kepulauan sehingga LPP TVRI berfungsi sebagai pemersatu bangsa dan pembentuk citra positif bangsa di dunia internasional serta identitas nasional. Selain itu TVRI bertugas menyiarkan informasi pendidikan, budaya, dan hiburan. Maka TVRI diharapkan dapat mewujudkan tujuan pembangunan nasional yang adil, makmur dan sejahtera.

LPP TVRI Stasiun NTT mempunyai visi, misi dan tujuan dengan menetapkan 2 (dua) sasaran strategis yang hendak dicapai yaitu: (1) Program Penyiaran Publik dan (2) Program Dukungan 
Manajemen Satker. Program penyiaran publik merupakan program yang mencerminkan tugas dan fungsi utama LPP TVRI yaitu: penyiaran program dan berita, dukungan teknik penyiaran, pengembangan usaha dan peningkatan sumber daya manusia. Sedangkan Program Dukungan Manajemen Satker bertujuan untuk mendukung pelaksanaan tugas dan fungsi utama LPP TVRI Stasiun NTT guna peningkatan kinerja manajemen internal dan akuntabilitas (Renstra TVRI 20202024).

Tabel 1. Realisasi Kinerja dari Sasaran dan Indikator Kinerja pada LPP TVRI Stasiun NTT

\begin{tabular}{|c|c|c|c|c|c|c|c|}
\hline \multirow{3}{*}{ No } & \multirow{3}{*}{ Sasaran } & & $L P P$ & & & $N T T$ & \\
\hline & & \multirow{2}{*}{$\begin{array}{c}\text { Indika } \\
\text { tor } \\
\text { sasara } \\
\text { n }\end{array}$} & \multicolumn{4}{|c|}{\begin{tabular}{|c|} 
Realisasi kinerja \\
sasaran pada tahun ke
\end{tabular}} & \multirow{2}{*}{$\begin{array}{c}\text { Rata- } \\
\text { rata }\end{array}$} \\
\hline & & & 2017 & 2018 & 2019 & 2020 & \\
\hline \multirow[t]{3}{*}{1} & \multirow{3}{*}{$\begin{array}{l}\text { Meningkat } \\
\text { nya } \\
\text { penyebara } \\
\text { n siaran } \\
\text { dan } \\
\text { meningkat } \\
\text { nya } \\
\text { kualitas } \\
\text { konten } \\
\text { (informasi, } \\
\text { pendidika } \\
\text { n, hiburan, } \\
\text { budaya, } \\
\text { religi) } \\
\text { yang } \\
\text { merata di } \\
\text { seluruh } \\
\text { wilayah } \\
\text { NTT }\end{array}$} & $\begin{array}{c}\text { Partisipa } \\
\text { si } \\
\text { masyara } \\
\text { kat } \\
\end{array}$ & $75 \%$ & $70 \%$ & $60 \%$ & $50 \%$ & $63,75 \%$ \\
\hline & & $\begin{array}{l}\text { Populasi } \\
\text { yang } \\
\text { terlayani } \\
\text { penyiara } \\
\text { n digital }\end{array}$ & $20 \%$ & $17 \%$ & $10 \%$ & $15 \%$ & $15,5 \%$ \\
\hline & & \begin{tabular}{|} 
Share \\
nilai \\
marketin \\
$\mathrm{g}$ \\
terhadap \\
pendapat \\
an
\end{tabular} & $65 \%$ & $70 \%$ & $75 \%$ & $80 \%$ & $72,5 \%$ \\
\hline \multirow[t]{3}{*}{2} & \multirow{3}{*}{$\begin{array}{l}\text { Meningkat } \\
\text { nya SDM } \\
\text { yang } \\
\text { handal }\end{array}$} & \begin{tabular}{|l} 
Pendidik \\
an (S1)
\end{tabular} & $25 \%$ & $25 \%$ & $20 \%$ & $17 \%$ & $21,75 \%$ \\
\hline & & Pelatihan & $65 \%$ & $65 \%$ & $50 \%$ & $40 \%$ & $55 \%$ \\
\hline & & \begin{tabular}{|c|} 
Kuantita \\
s
\end{tabular} & $55 \%$ & $55 \%$ & $50 \%$ & $45 \%$ & $51,25 \%$ \\
\hline \multirow[t]{3}{*}{3} & \multirow{3}{*}{$\begin{array}{l}\text { Meningkat } \\
\text { nya } \\
\text { kualitas } \\
\text { sarana dan } \\
\text { prasarana }\end{array}$} & Gedung & $30 \%$ & $45 \%$ & $50 \%$ & $55 \%$ & $45 \%$ \\
\hline & & $\begin{array}{l}\text { Peralatan } \\
\text { transmisi }\end{array}$ & $10 \%$ & $15 \%$ & $18 \%$ & $20 \%$ & $15,75 \%$ \\
\hline & & $\begin{array}{l}\text { Peralatan } \\
\text { TPP }\end{array}$ & $40 \%$ & $50 \%$ & $58 \%$ & $65 \%$ & $53,25 \%$ \\
\hline
\end{tabular}

Kinerja pada LPP TVRI stasiun NTT didapat dari kinerja karyawan yang ada pada lembaga tersebut. Berdasarkan tabel 1, pada sasaran 1 dan indikatornya menunjukan realisasi kinerja dari tahun 2017 hingga 2020 terus mengalami penurunan. Sasaran 1 ini berkaitan erat dengan kinerja karyawan yang keberhasilannya dapat diukur berdasarkan indikator sasaran 1 yaitu partisipasi masyarakat, populasi yang terlayani penyiaran digital, dan share nilai marketing terhadap pendapatan. Sasaran 2 dengan indikatornya yaitu pendidikan, pelatihan dan kuantitas juga tidak dapat ditingkatkan. Pada realisasi kinerja sasaran 2 ini menunjukan perkembangan SDM di LPP TVRI stasiun NTT yang mengalami penurunan setiap tahunnya dari 2017 hingga 2020. Meskipun pada sasaran 3 terdapat peningkatan namun tingkat realisasi kinerja menunjukan bahwa sasaran 3 masih harus ditingkatkan.

Berdasarkan kondisi tersebut, penelitian ini bertujuan untuk menganalisis empat faktor yang dapat mempengaruhi kinerja karyawan antara lain teknologi informasi, motivasi, lingkungan kerja dan organizational citizenship behavior (OCB) dengan dukungan sosial sebagai variabel pemoderasi.

\section{TINJAUAN PUSTAKA}

\section{Pengertian Kinerja}

Menurut Prawirosentono dalam Sinambela (2006, p. 137) kinerja adalah hasil kerja yang dicapai oleh pegawai atau sekelompok pegawai sesuai dengan wewenang dan tanggung jawab masing-masing, dalam upaya mencapai tujuan organisasi bersangkutan secara legal, tidak melanggar hukum dan sesuai dengan moral dan etika. Sedangkan, Mangkunegara (2010, p. 67) mendefinisikan kinerja sebagai hasil kerja baik secara kualitas maupun kuantitas yang dicapai oleh seorang pegawai ketika melaksanakan tugasnya sesuai dengan tanggung jawabnya.

\section{Pengertian Teknologi Informasi}

Haag dan Keen (1996) mengatakan teknologi informasi merupakan seperangkat alat yang bertugas untuk membantu pekerjaan dalam memproses informasi. Sedangkan, menurut Leitch Rosses dalam Jugiyanto (2005, p 11) menyatakan bahwa sistem teknologi informasi menunjukkan suatu sistem teknologi di dalam organisasi yang berfungsi untuk mengolah transaksi harian, mendukung operasi, baik yang bersifat manajerial maupun strategis, serta menyediakan laporanlaporan yang diperlukan untuk pihak luar (eksternal). 


\section{Pengertian Lingkungan Kerja}

Menurut Sedarmayanti (2011), lingkungan kerja didefinisikan sebagai keseluruhan alat perkakas kerja, bahan kerja, metode kerja, aturan kerja yang dihadapi ketika seseorang bekerja baik sebagai perseorangan maupun kelompok. Nitisemito (2008) mengatakan bahwa lingkungan kerja juga merupakan segala sesuatu yang ada disekitar para pekerja yang dapat mempengaruhi dirinya dalam menjalankan tugas-tugas yang dibebankan dan merupakan salah satu faktor yang mempengaruhi kinerja seorang pegawai.

\section{Pengertian Motivasi Kerja}

Winardi (2016, p. 6) mengemukakan bahwa motivasi merupakan kekuatan potensial manusia, yang dapat dikembangkan sendiri atau melalui sejumlah kekuatan luar. Motivasi dapat berupa imbalan moneter dan imbalan non moneter, yang dapat mempengaruhi kinerja seseorang baik secara positif maupun negatif. Malayu (2015, p. 23) menyatakan bahwa motivasi terkait dengan cara mendorong gairah kerja bawahan agar mau berkerja keras dengan memberikan semua kemampuan dan keterampilannya untuk mewujudkan tujuan perusahaan.

\section{Pengertian Organizational Citizenship Behavior}

Djati dalam Nahrisah \& Imelda (2019) mengatakan bahwa organizational citizenship behavior adalah pilihan bentuk perilaku dan inisiatif individual untuk meningkatkan efisiensi kinerja organisasi dengan membantu tujuan produktifitas karyawan. Selanjutnya Chiang \& Hiesh dalam Aisyah (2020) menyebutkan bahwa organizational citizenship behavior merupakan sikap dalam pekerjaan yang melebihi kadar pekerjaan utama seorang karyawan.

\section{Hipotesis}

Penggunaan teknologi informasi dalam sebuah instansi pemerintahan harus didukung oleh kinerja pegawai yang kompeten dalam menggunakan teknologi informasi tersebut. Teknologi informasi sangat dibutuhkan dalam perusahaan ataupun instansi pemerintahan, baik itu negeri maupun swasta, teknologi informasi sangat diperlukan untuk membantu kegiatan operasional. Dengan peralatan teknologi yang canggih akan mempercepat kinerja dan memberikan hasil yang maksimal bagi instansi pemerintahan. Selain itu, para pegawai akan merasa puas bekerja dengan menggunakan teknologi.

Hal tersebut didukung dengan penelitian yang dilakukan oleh Ni Putu dan Gusti (2014) dan Handayani, Runtuwene dan Sambu (2018) menyimpulkan bahwa teknologi informasi berpengaruh positif dan signifikan terhadap kinerja.

Berdasarkan pejelasan diatas maka dirumuskan hipotesis sebagai berikut:

H1: Teknologi informasi berpengaruh signifikan terhadap kinerja pegawai LLP TVRI Stasiun NTT.

Lingkungan kerja adalah segala sesuatu yang ada disekitar para pekerja yang dapat mempengaruhi dirinya sendiri dalam menjalankan tugasnya. Lingkungan kerja juga harus diperhatikan oleh manajemen karena lingkungan berpengaruh langsung terhadap para karyawan yang berada di perusahaan tersebut. Lingkungan yang nyaman dapat meningkatkan kinerja karyawan itu sendiri (Nurtjahjono, 2014).

Penelitian yang dilakukan oleh Ferawati (2017) dan Hidayat \& Muchamad (2012) menyimpulkan bahwa lingkungan kerja berpengaruh positif dan signifikan terhadap kinerja karyawan.

Berdasarkan pejelasan diatas maka dirumuskan hipotesis sebagai berikut:

$\mathrm{H} 2$ : Lingkungan kerja berpengaruh signifikan terhadap kinerja pegawai LPP TVRI Stasiun NTT.

Menurut Lomban et al., (2015), menyatakan motivasi kerja merupakan salah satu bagian dari manajemen sumber daya manusia dalam melakukan suatu pekerjaan agar timbul semangat dan kegairahan dalam bekerja. Di sisi lain, setiap karyawan memiliki perbedaan motivasi kerja dalam pengembangan, pengarahan, dan peningkatan efektivitas kinerja individu.

Penelitian yang dilakukan oleh Nurtjahjono (2014), Paputungan (2013), Turang et al., (2015), dan Kasim et. al., (2016) menunjukkan 
bahwa motivasi kerja berpengaruh positif signifikan terhadap kinerja karyawan.

Berdasarkan pejelasan diatas maka dirumuskan hipotesis sebagai berikut:

H3: Motivasi kerja berpengaruh signifikan terhadap kinerja pegawai LPP TVRI Stasiun NTT.

Djati dalam Nahrisah \& Imelda (2019) memberikan pengertian organizational citizenship behavior (OCB) sebagai bentuk perilaku yang merupakan pilihan dan inisiatif individual untuk meningkatkan efisiensi kinerja organisasi dengan membantu tujuan produktivitas karyawan.

Hasil penelitian terdahulu dari Purnama (2013) menemukan bahwa dengan dilakukannya Organizational citizenship behavior, maka akan meningkatkan kinerja karyawan.

Berdasarkan pejelasan diatas maka dirumuskan hipotesis sebagai berikut:

H4: Organizational citizenship behavior berpengaruh signifikan terhadap kinerja pegawai LPP TVRI Stasiun NTT.

Agar kinerja karyawan dapat dipertahankan, maka perlu adanya dukungan sosial terhadap para karyawan. Lambert et al. (2016) menyatakan bahwa memberikan dukungan sosial seperti dukungan psikologis, bantuan, umpan balik, dan motivasi untuk para karyawan akan sangat berharga bagi karyawan. Sistem dukungan sosial dapat memberikan dorongan, yang dapat mengakibatkan lebih cepat mendapatkan solusi untuk masalah di tempat kerja, sehingga pekerjaan menjadi lebih produktif dan menyenangkan.

Adapun penelitian dari Setyowati \& Nurhidayati (2015) menyatakan bahwa variabel dukungan sosial sangat berpengaruh terhadap peningkatan kinerja.

Berdasarkan pejelasan diatas maka dirumuskan hipotesis sebagai berikut:

H5: Dukungan sosial dapat memoderasi pengaruh teknologi informasi terhadap kinerja pegawai LPP TVRI Stasiun NTT.

H6: Dukungan sosial dapat memoderasi pengaruh lingkungan kerja terhadap kinerja pegawai LPP TVRI Stasiun NTT.
$\mathrm{H} 7$ : Dukungan sosial dapat memoderasi pengaruh motivasi kerja terhadap kinerja pegawai LPP TVRI Stasiun NTT.

H8: Dukungan sosial dapat memoderasi pengaruh OCB terhadap kinerja pegawai LPP TVRI Stasiun NTT.

\section{Kerangka Berpikir}

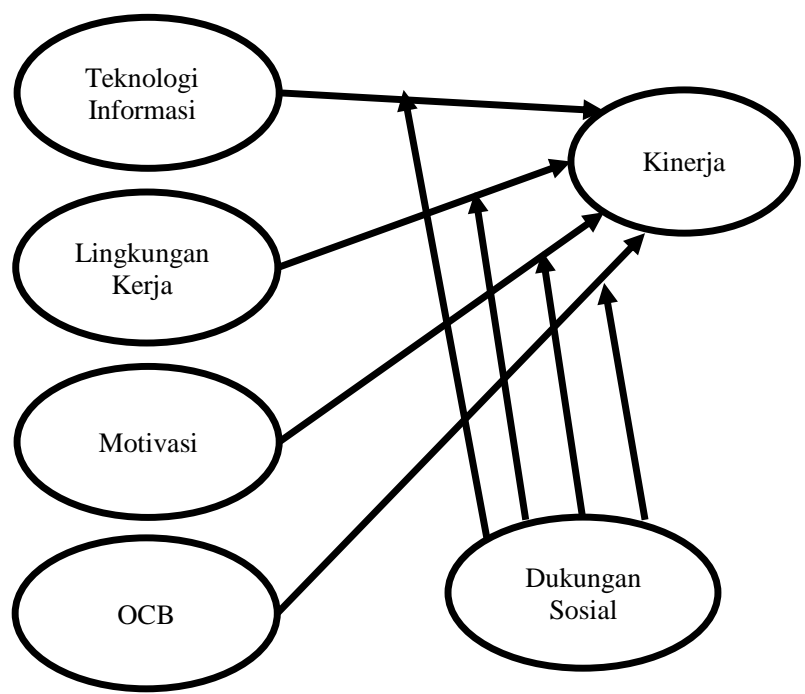

Gambar 1. Kerangka Berpikir

\section{METODOLOGI}

\section{Jenis Penelitian}

Jenis penelitian yang digunakan dalam penelitian ini adalah penelitian survey kuantitatif. Teknik pengumpulan data dalam penelitian ini menggunakan wawancara, studi dokumen dan kuesioner.

\section{Populasi dan Sampel}

Populasi yang menjadi fokus dalam penelitian ini adalah seluruh pegawai LPP TVRI Stasiun NTT yang berjumlah 61 orang.

Dalam penelitian ini menggunakan sampling total. Sugiyono (2013, p. 85) menyatakan bahwa sampling total adalah teknik penentuan sampel bila semua anggota populasi digunakan sebagai sampel. Untuk itu, yang menjadi sampel dalam penelitian ini adalah seluruh pegawai pada LPP TVRI Stasiun NTT yang berjumlah 61 orang.

\section{Operasional Variabel}

Dalam penelitian ini akan dianalisis enam variabel yakni empat variabel bebas yaitu teknologi informasi (X1), lingkungan kerja (X2), 
motivasi kerja (X3), dan organizational citizenship behavior (X4), satu variabel moderasi yakni dukungan sosial (Z) serta satu variabel terikat yaitu kinerja pegawai LPP TVRI Stasiun NTT (Y).

Definisi operasional dari setiap variabel yang akan dianalisis adalah sebagai berikut:

Tabel 2. Operasional Variabel

\begin{tabular}{|c|c|c|}
\hline Variabel & Indikator & $\begin{array}{c}\text { Pengukura } \\
n\end{array}$ \\
\hline Teknologi & 1. Perangkat Keras (Hardware) & Skala \\
\hline $\begin{array}{l}\text { Informasi } \\
(\mathrm{X} 1)\end{array}$ & $\begin{array}{l}\text { 2. Perangkat lunak (Software) } \\
\text { 3. Manusia (Brainware) }\end{array}$ & Likert \\
\hline $\begin{array}{l}\text { Lingku- } \\
\text { ngan } \\
\text { Kerja } \\
\text { (X2) }\end{array}$ & $\begin{array}{l}\text { 1. Sirkulasi Udara } \\
\text { 2. Kebersihan } \\
\text { 3. Penerangan } \\
\text { 4. Sarana prasarana kantor } \\
\end{array}$ & $\begin{array}{l}\text { Skala } \\
\text { Likert }\end{array}$ \\
\hline $\begin{array}{l}\text { Motivasi } \\
\text { Kerja } \\
\text { (X3) }\end{array}$ & $\begin{array}{l}\text { 1. Keinginan untuk berprestasi } \\
\text { 2. Keinginan untuk melakukan } \\
\text { perbaikan } \\
\text { 3. Keinginan untuk melakukan } \\
\text { perubahan } \\
\text { 4. Keinginan untuk senantiasa } \\
\text { untuk meningkatkan } \\
\text { kemampuan kerja } \\
\text { 5. Keinginan memperbaiki } \\
\text { hubungan kerja }\end{array}$ & $\begin{array}{l}\text { Skala } \\
\text { Likert }\end{array}$ \\
\hline $\begin{array}{l}\text { Organiza- } \\
\text { tional } \\
\text { Citizen- } \\
\quad \text { ship } \\
\text { Behavior } \\
\quad \text { (X4) }\end{array}$ & $\begin{array}{l}\text { 1. Altruism (membantu orang } \\
\text { lain secara sukarela) } \\
\text { 2. Conscientiousness (melebihi } \\
\text { standar yang diharapkan) } \\
\text { 3. Sportsmanship (menghindari } \\
\text { ketegangan dengan memelihara } \\
\text { suasana yang nyaman) } \\
\text { 4. Courtesy (menjaga hubungan } \\
\text { baik dengan rekan kerja) } \\
\text { 5. Civic Virtue (ketertarikan dan } \\
\text { kesetiaan yang tinggi terhadap } \\
\text { organisasi) }\end{array}$ & $\begin{array}{l}\text { Skala } \\
\text { Likert }\end{array}$ \\
\hline $\begin{array}{l}\text { Dukungan } \\
\text { Sosial (Z) }\end{array}$ & $\begin{array}{c}\text { 1. Dukungan emosi } \\
\text { 2. Dukungan penghargaan } \\
\text { 3. Dukungan instrumental dan } \\
\text { konkrit } \\
\text { 4. Dukungan informasi } \\
\text { 5. Dukungan jaringan sosial. }\end{array}$ & $\begin{array}{l}\text { Skala } \\
\text { Likert }\end{array}$ \\
\hline $\begin{array}{c}\text { Kinerja } \\
\text { Karyawan } \\
(\mathrm{Y})\end{array}$ & $\begin{array}{l}\text { 1. Kuantitas kerja } \\
\text { 2. Kualitas kerja } \\
\text { 3. Pengetahuan pekerjaan } \\
\text { 4. Kerja sama } \\
\text { 5. Ketepatan waktu }\end{array}$ & $\begin{array}{c}\text { Skala } \\
\text { Likert }\end{array}$ \\
\hline
\end{tabular}

\section{Teknik Pengumpulan dan Analisis Data}

Penelitian ini menggunakan data primer dan sekunder. Pengumpulan data melalui wawancara, kuesioner dan dokumentasi. Teknik analisis data menggunakan analisis statistik deskriptif dan analisis statistik inferensial dengan alat uji statistik Partial Least Square (PLS) menggunakan software SmartPLS 3.2.8.

\section{HASIL DAN PEMBAHASAN}

\section{Analisis Deskriptif Teknologi Informasi}

Tabel 3. Analisis Deskriptif Teknologi Informasi

\begin{tabular}{|c|c|c|c|c|c|c|c|c|}
\hline $\begin{array}{l}\mathrm{N} \\
\mathrm{o}\end{array}$ & Indikator & $\begin{array}{c}\text { Ite } \\
\mathrm{m}\end{array}$ & $\sum$ & $\begin{array}{c}\mathrm{X} P \mathrm{~s}- \\
\mathrm{p}\end{array}$ & $\begin{array}{l}\bar{X} \text { Ps- } \\
\text { p)/5 }\end{array}$ & Ps - p & Skor & $\begin{array}{c}\text { Kategor } \\
\text { i } \\
\end{array}$ \\
\hline 1 & Perangkat & 1 & 230 & 3,77 & 0,75 & 75 & \multirow{2}{*}{75} & \multirow{2}{*}{ Baik } \\
\hline & (Hardware) & 2 & 230 & 3,77 & 0,75 & 75 & & \\
\hline \multirow[t]{2}{*}{2} & Perangkat & 3 & 216 & 3.54 & 0,71 & 71 & \multirow{2}{*}{71} & \multirow{2}{*}{ Baik } \\
\hline & (Software) & 4 & 217 & 3.56 & 0,71 & 71 & & \\
\hline \multirow[t]{2}{*}{3} & Manusia & 5 & 199 & 3.26 & 0,65 & 65 & \multirow{2}{*}{67} & \multirow{2}{*}{$\begin{array}{c}\text { Cukup } \\
\text { baik }\end{array}$} \\
\hline & $($ Brainware $)$ & 6 & 209 & 3.42 & 0,68 & 68 & & \\
\hline \multicolumn{7}{|c|}{ Rata-rata } & 71 & Baik \\
\hline
\end{tabular}

Berdasarkan tabel diatas, teknologi informasi berada pada kategori Baik, dengan ratarata nilai skor sebesar $71 \%$. Indikator dengan capaian tertinggi adalah perangkat keras (hardware) sebesar $75 \%$ dan indikator dengan capaian skor terendah adalah indikator manusia yaitu sebesar $67 \%$.

\section{Analisis Deskriptif Lingkungan Kerja}

Tabel 4. Analisis Deskriptif Lingkungan Kerja

\begin{tabular}{|c|c|c|c|c|c|c|c|c|}
\hline $\begin{array}{l}\mathbf{N} \\
\mathbf{0}\end{array}$ & Indikator & $\begin{array}{c}\text { Ite } \\
\text { m }\end{array}$ & $\sum$ & $\begin{array}{c}\overline{\mathbf{X} P s}- \\
\mathbf{p}\end{array}$ & $\begin{array}{c}(\overline{\mathbf{X}} \text { Ps - } \\
\mathbf{p}) / \mathbf{5}\end{array}$ & $\begin{array}{c}\text { Ps - } \\
\text { p }\end{array}$ & Skor & $\begin{array}{c}\text { Katego } \\
\text { ri }\end{array}$ \\
\hline \multirow{2}{*}{1} & \multirow{2}{*}{ Sirkulasi } & 7 & 227 & 3,72 & 0,74 & 74 & \multirow{2}{*}{71} & \multirow{2}{*}{ Baik } \\
\hline & & 8 & 208 & 3,41 & 0.68 & 68 & & \\
\hline \multirow{2}{*}{2} & Kebersiha & 9 & 228 & 3,74 & 0.74 & 74 & \multirow{2}{*}{72,5} & \multirow{2}{*}{ Baik } \\
\hline & $\mathrm{n}$ & 10 & 218 & 3,57 & 0,71 & 71 & & \\
\hline \multirow{2}{*}{3} & Peneranga & 11 & 226 & 3,70 & 0.74 & 74 & \multirow{2}{*}{73} & \multirow{2}{*}{ Baik } \\
\hline & $\mathrm{n}$ & 12 & 220 & 3,61 & 0.72 & 72 & & \\
\hline \multirow{2}{*}{4} & Sarana & 13 & 241 & 3,95 & 0.79 & 79 & \multirow{2}{*}{77} & \multirow{2}{*}{ Baik } \\
\hline & Prasarana & 14 & 229 & 3,75 & 0.75 & 75 & & \\
\hline \multicolumn{7}{|c|}{ Rata-rata } & $\mathbf{7 3 . 4 0}$ & Baik \\
\hline
\end{tabular}

Berdasarkan tabel diatas terlihat bahwa capaian indikator dari variabel lingkungan kerja memperoleh skor rata-rata $73,40 \%$. Nilai terendah pada indikator sirkulasi udara yaitu $71 \%$ dan nilai tertinggi adalah pada indikator sarana prasarana yaitu sebesar 77\%. Dengan skor capaian ini, dapat disimpulkan bahwa lingkungan kerja berada dalam standar Baik. 
Analisis Deskriptif Motivasi Kerja

Tabel 5. Analisis Deskriptif Motivasi Kerja

\begin{tabular}{|c|c|c|c|c|c|c|c|c|}
\hline $\begin{array}{l}\mathbf{N} \\
\mathbf{o}\end{array}$ & Indikator & $\begin{array}{c}\text { Ite } \\
\text { m }\end{array}$ & $\sum$ & $\begin{array}{c}\mathbf{X} \mathbf{P} s \text { - } \\
\mathbf{p}\end{array}$ & $\begin{array}{c}(\overline{\mathbf{X}} \text { Ps - } \\
\text { p) }) / 5\end{array}$ & $\begin{array}{c}\text { Ps - } \\
\text { p }\end{array}$ & $\begin{array}{c}\text { Sko } \\
\text { r }\end{array}$ & $\begin{array}{c}\text { Katego } \\
\text { ri }\end{array}$ \\
\hline \multirow[b]{2}{*}{1} & Keinginan & 15 & 236 & 3,86 & 0,77 & 77 & \multirow[b]{2}{*}{77,5} & \multirow[b]{2}{*}{ Baik } \\
\hline & $\begin{array}{c}\text { untuk } \\
\text { berprestasi }\end{array}$ & 16 & 238 & 3,90 & 0,78 & 78 & & \\
\hline \multirow[b]{2}{*}{2} & Keinginan & 17 & 214 & 3,51 & 0.70 & 70 & \multirow[b]{2}{*}{71} & \multirow[b]{2}{*}{ Baik } \\
\hline & $\begin{array}{c}\text { untuk } \\
\text { melakukan } \\
\text { perbaikan }\end{array}$ & 18 & 220 & 3,61 & 0,72 & 72 & & \\
\hline \multirow[b]{2}{*}{3} & \multirow{2}{*}{$\begin{array}{c}\text { Keinginan } \\
\text { untuk } \\
\text { melakukan } \\
\text { perubahan }\end{array}$} & 19 & 210 & 3,44 & 0,69 & 69 & \multirow[b]{2}{*}{69} & \multirow[b]{2}{*}{ Baik } \\
\hline & & 20 & 212 & 3,47 & 0,69 & 69 & & \\
\hline \multirow[b]{2}{*}{4} & \multirow[b]{2}{*}{$\begin{array}{c}\text { Keinginan } \\
\text { untuk } \\
\text { meningkatk } \\
\text { an } \\
\text { kemampuan } \\
\text { kerja }\end{array}$} & 21 & 218 & 3,57 & 0,71 & 71 & \multirow[b]{2}{*}{71} & \multirow[b]{2}{*}{ Baik } \\
\hline & & 22 & 216 & 3,54 & 0,71 & 71 & & \\
\hline \multirow[b]{2}{*}{5} & \multirow{2}{*}{$\begin{array}{c}\text { Keinginan } \\
\text { memperbai } \\
\text { ki } \\
\text { hubungan } \\
\text { kerja }\end{array}$} & 23 & 228 & 3,74 & 0,75 & 75 & \multirow[b]{2}{*}{76} & \multirow[b]{2}{*}{ Baik } \\
\hline & & 24 & 237 & 3,88 & 0,77 & 77 & & \\
\hline \multicolumn{7}{|c|}{ Rata-rata } & 73 & Baik \\
\hline
\end{tabular}

Berdasarkan analisis tanggapan responden pada tabel diatas terlihat bahwa capaian indikator dari variabel motivasi kerja memperoleh nilai ratarata sebesar $73 \%$. Nilai terendah adalah pada indikator keinginan untuk melakukan perubahan yaitu $69 \%$ dan nilai tertinggi ada pada indikator keinginan untuk memperbaiki hubungan kerja yaitu $76 \%$. Dengan capaian skor ini, dapat disimpulkan bahwa motivasi kerja berada dalam kategori Baik

\section{Analisis Deskriptif Organizational Citizenship Behavior}

Tabel 6. Analisis Deskriptif Organizational Citizenship Behavior

\begin{tabular}{|c|c|c|c|c|c|c|c|c|}
\hline No & $\begin{array}{c}\text { Indik } \\
\text { ator }\end{array}$ & Item & $\sum$ & $\begin{array}{c}\overline{\mathbf{X} P s} \\
\mathbf{p}\end{array}$ & $\begin{array}{r}(\overline{\mathbf{X}} \mathbf{P s} \\
\mathbf{p}) / \mathbf{5}\end{array}$ & $\begin{array}{l}\text { Ps - } \\
\text { p }\end{array}$ & Skor & Kategori \\
\hline \multirow{2}{*}{1} & \multirow{2}{*}{$\begin{array}{c}\text { Altrui } \\
\text { sm }\end{array}$} & 25 & 238 & 3,90 & 0,78 & 78 & \multirow{2}{*}{75,5} & \multirow{2}{*}{ Baik } \\
\hline & & 26 & 222 & 3,64 & 0,73 & 73 & & \\
\hline \multirow[b]{2}{*}{2} & \multirow{2}{*}{$\begin{array}{l}\text { Consc } \\
\text { ientio } \\
\text { uness }\end{array}$} & 27 & 233 & 3,82 & 0,76 & 76 & \multirow{2}{*}{73,5} & \multirow{2}{*}{ Baik } \\
\hline & & 28 & 216 & 3,54 & 0,71 & 71 & & \\
\hline \multirow[b]{2}{*}{3} & Sport & 29 & 221 & 3,62 & 0,72 & 72 & \multirow[b]{2}{*}{70} & \multirow[b]{2}{*}{ Baik } \\
\hline & $\begin{array}{c}\text { smans } \\
\text { hip }\end{array}$ & 30 & 209 & 3,43 & 0,68 & 68 & & \\
\hline \multirow{2}{*}{4} & Court & 31 & 221 & 3,62 & 0,72 & 72 & \multirow{2}{*}{73} & \multirow{2}{*}{ Baik } \\
\hline & esy & 32 & 226 & 3,70 & 0,74 & 74 & & \\
\hline \multirow{2}{*}{5} & \multirow{2}{*}{$\begin{array}{l}\text { Civic } \\
\text { Virtue }\end{array}$} & 33 & 218 & 3,57 & 0,71 & 71 & \multirow{2}{*}{72,5} & \multirow{2}{*}{ Baik } \\
\hline & & 34 & 227 & 3,72 & 0,74 & 74 & & \\
\hline \multicolumn{7}{|c|}{ Rata-rata } & 73 & Baik \\
\hline
\end{tabular}

Berdasarkan deskripsi jawaban responden terhadap variabel organizational citizenship behavior pada tabel diatas dapat dijelaskan bahwa organizational citizenship behavior berada pada kategori Baik dengan rata-rata skor sebesar $73 \%$. Indikator dengan capaian tertinggi adalah Altruism (membantu orang lain secara sukarela) dengan skor $75,5 \%$ dan indikator dengan capaian terendah adalah Sportsmanship (menghindari ketegangan dengan memelihara suasana yang nyaman) yaitu sebesar $70 \%$.

\section{Analisis Deskriptif Dukungan Sosial}

Tabel 7. Analisis Deskripttif Dukungan Sosial

\begin{tabular}{|c|c|c|c|c|c|c|c|c|}
\hline No & Indikator & Item & $\sum$ & $\begin{array}{c}\mathbf{X} \mathbf{P} \text { s }- \\
\mathbf{p}\end{array}$ & $\left(\begin{array}{l}\overline{\mathbf{X}} \text { Ps } \\
-\mathbf{p}) / 5\end{array}\right.$ & $\begin{array}{r}\text { Ps } \\
-\mathbf{p}\end{array}$ & Skor & $\begin{array}{l}\text { Kate } \\
\text { gori }\end{array}$ \\
\hline \multirow{2}{*}{1} & Dukungan & 35 & 250 & 4,09 & 0,82 & 82 & \multirow{2}{*}{82} & \multirow{2}{*}{ Baik } \\
\hline & Emosi & 36 & 250 & 4,09 & 0,82 & 82 & & \\
\hline \multirow[b]{2}{*}{2} & Dukungan & 37 & 239 & 3,92 & 0,78 & 78 & \multirow[b]{2}{*}{78} & \multirow[b]{2}{*}{ Baik } \\
\hline & $\begin{array}{c}\text { penghargaa } \\
n\end{array}$ & 38 & 239 & 3,92 & 0,78 & 78 & & \\
\hline \multirow[b]{2}{*}{3} & Dukungan & 39 & 249 & 4,08 & 0,81 & 81 & \multirow[b]{2}{*}{81} & \multirow[b]{2}{*}{ Baik } \\
\hline & $\begin{array}{c}\text { instrument } \\
\text { al dan } \\
\text { konkrit } \\
\end{array}$ & 40 & 248 & 4,06 & 0,81 & 81 & & \\
\hline \multirow{2}{*}{4} & Dukungan & 41 & 238 & 3,90 & 0,78 & 78 & \multirow{2}{*}{79,5} & \multirow{2}{*}{ Baik } \\
\hline & informasi & 42 & 248 & 4,06 & 0,81 & 81 & & \\
\hline \multirow[b]{2}{*}{5} & Dukungan & 43 & 246 & 4,03 & 0,81 & 81 & \multirow[b]{2}{*}{81} & \multirow[b]{2}{*}{ Baik } \\
\hline & $\begin{array}{c}\text { jaringan } \\
\text { Sosial. }\end{array}$ & 44 & 246 & 4,03 & 0,81 & 81 & & \\
\hline \multicolumn{7}{|c|}{ Rata-rata } & $\mathbf{8 0 , 3}$ & Baik \\
\hline
\end{tabular}

Berdasarkan data pada tabel diatas maka dapat dijelaskan bahwa variabel dukungan sosial berada dalam kategori Baik dengan rata-rata skor sebesar $80,3 \%$. Dari 5 indikator yang dianalisis, semuanya masuk dalam kategori Baik. Indikator dengan capaian tertinggi adalah dukungan emosi dengan nilai sebesar $82 \%$ dan indikator dengan capaian terendah adalah dukungan penghargaan dengan skor sebesar $78 \%$.

\section{Analisis Deskriptif Kinerja}

Berdasarkan deskripsi jawaban responden, terlihat bahwa skor indikator dari variabel kinerja memperoleh rata-rata nilai skor sebesar $79 \%$. Nilai terendah terdapat pada indikator kualitas kerja yaitu $77 \%$ dan nilai tertinggi ada pada indikator pengetahuan pekerjaan yaitu $81,5 \%$. Dengan capaian skor ini, dapat disimpulkan bahwa variabel kinerja berada dalam kategori Baik. 
Tabel 8. Analisis Deskriptif Kinerja

\begin{tabular}{|c|c|c|c|c|c|c|c|c|}
\hline $\begin{array}{l}\mathbf{N} \\
\mathbf{0}\end{array}$ & Indikator & $\begin{array}{l}\text { Ite } \\
\text { m }\end{array}$ & $\Sigma$ & $\mathbf{X P s}-\mathbf{p}$ & $\begin{array}{c}(\overline{\mathbf{X}} \mathbf{P s}- \\
\mathbf{p}) / \mathbf{5}\end{array}$ & $\begin{array}{c}\text { Ps - } \\
\text { p }\end{array}$ & \begin{tabular}{|c|} 
Sko \\
$\mathbf{r}$ \\
\end{tabular} & $\begin{array}{c}\text { Katego } \\
\text { ri }\end{array}$ \\
\hline \multirow{2}{*}{1} & \multirow{2}{*}{$\begin{array}{c}\text { Kuantitas } \\
\text { Kerja }\end{array}$} & 45 & 242 & 3,97 & 0,79 & 79 & \multirow{2}{*}{79} & \multirow{2}{*}{ Baik } \\
\hline & & 46 & 242 & 3,79 & 0,79 & 79 & & \\
\hline \multirow{2}{*}{2} & \multirow{2}{*}{ Kualitas Kerja } & 47 & 236 & 3,87 & 0.77 & 77 & \multirow{2}{*}{77} & \multirow{2}{*}{ Baik } \\
\hline & & 48 & 237 & 3,88 & 0,77 & 77 & & \\
\hline \multirow{2}{*}{3} & \multirow{2}{*}{$\begin{array}{c}\text { Pengetahuan } \\
\text { Pekerjaan }\end{array}$} & 49 & 249 & 4,08 & 0,82 & 82 & \multirow{2}{*}{81.5} & \multirow{2}{*}{ Baik } \\
\hline & & 50 & 248 & 4,06 & 0,81 & 81 & & \\
\hline \multirow{2}{*}{4} & \multirow{2}{*}{ Kerjasama } & 51 & 239 & 3,92 & 0.78 & 78 & \multirow{2}{*}{79} & \multirow{2}{*}{ Baik } \\
\hline & & 52 & 244 & 4,00 & 0,80 & 80 & & \\
\hline \multirow{2}{*}{5} & Ketepatan & 53 & 241 & 3,95 & 0.79 & 79 & \multirow{2}{*}{79} & \multirow{2}{*}{ Baik } \\
\hline & Woktu & 54 & 241 & 3,95 & 0.79 & 79 & & \\
\hline \multicolumn{7}{|c|}{ Rata-rata } & 79 & Baik \\
\hline
\end{tabular}

\section{Average Variance Extracted (AVE)}

Nilai Average Variance Extracted (AVE) digunakan untuk mengetahui apakah variabel laten memiliki diskriminan yang memadai, yaitu dengan cara membandingkan korelasi indikator dengan variabel latennya. Variabel laten harus lebih besar dibandingkan dengan korelasi antar indikator dengan variabel lain. Jika korelasi indikator dengan variabel laten memiliki nilai yang lebih tinggi dibandingkan dengan korelasi indikator tersebut terhadap variabel laten lain maka dapat dikatakan variabel laten tersebut memiliki validitas yang tinggi. Standar nilai AVE adalah $>0,5$. Nilai Average Variance Extracted (AVE) tiap variabel adalah sebagai berikut:

Tabel 9. Average variance extracted

\begin{tabular}{|c|c|}
\hline Variabel & $\begin{array}{c}\text { Average variance } \\
\text { extracted (AVE) }\end{array}$ \\
\hline Kinerja Pegawai (Y) & 0,620 \\
\hline Teknologi informasi (X1) & 0,649 \\
\hline Lingkungan kerja (X2) & 0,655 \\
\hline Motivasi kerja (X3) & 0,601 \\
\hline $\begin{array}{c}\text { Organizational } \\
\text { Citizenship Behavior } \\
\text { (X4) }\end{array}$ & 0,675 \\
\hline Dukungan sosial (Z) & 0,627 \\
\hline
\end{tabular}

Dari hasil tabel di atas, terlihat bahwa seluruh variabel yang diteliti memperoleh nilai AVE $>0,50$ sehingga dapat disimpulkan bahwa masing-masing konstruk dalam penelitian ini tidak memiliki permasalahan dan layak digunakan.

\section{Discriminant Validity}

Discriminant validity merupakan bagian dari outer model. Syarat validitas diskriminan adalah hasil dalam view combined loading and cross-loadings menunjukkan bahwa loading ke konstruk lain (cross-loading) bernilai lebih rendah daripada loading ke konstruk variabel. Nilai discriminant validity harus lebih besar dari 0,70 untuk semua variabel. dapat dilihat pada tabel berikut:

Dari hasil pada tabel 11, terlihat bahwa seluruh variabel yang diteliti memperoleh nilai > 0,70 sehingga dapat disimpulkan bahwa masingmasing konstruk dalam penelitian ini tidak memiliki permasalahan dan layak digunakan.

\section{Composite Reliability}

Penilaian dari composite reliability ini dilakukan dengan melihat output dari view latent variabel coefficients. Uji ini untuk mengukur internal consistency dan nilainya harus $>0,7$. Nilai composite reliability tiap variabel dalam penelitian ini dapat dilihat pada tabel berikut:

Tabel 10. Composite Reliability

\begin{tabular}{|c|c|}
\hline Variabel & Reliability \\
\hline Kinerja & 0,891 \\
\hline Teknologi informasi & 0,847 \\
\hline Lingkungan kerja & 0,883 \\
\hline Motivasi kerja & 0,882 \\
\hline $\begin{array}{c}\text { Organizational Citizenship } \\
\text { Behavior }\end{array}$ & 0,912 \\
\hline Dukungan sosial & 0,870 \\
\hline
\end{tabular}

Dari hasil pada tabel 10, terlihat bahwa nilai composite reliability tiap variabel kinerja adalah > 0,7. Dengan demikian, dapat disimpulkan bahwa semua konstruk memiliki reliabilitas yang baik sesuai dengan batas nilai minimum yang disyaratkan. 
Tabel 11. Discriminant Validity

\begin{tabular}{|c|c|c|c|c|c|c|}
\hline & $\begin{array}{l}\text { Teknologi } \\
\text { Informasi }\end{array}$ & $\begin{array}{c}\text { Lingkungan } \\
\text { Kerja }\end{array}$ & Motivasi Kerja & OCB & Dukungan Sosial & Kinerja Kerja \\
\hline $\mathrm{X} 1.1$ & $\mathbf{0 , 8 0 3}$ & 0,553 & 0,651 & 0,498 & 0,504 & 0,587 \\
\hline $\mathrm{X} 1.2$ & $\mathbf{0 , 8 2}$ & 0,66 & 0,665 & 0,651 & 0,606 & 0,709 \\
\hline $\mathrm{X} 1.3$ & 0,793 & 0,686 & 0,723 & 0,587 & 0,589 & 0,661 \\
\hline $\mathrm{X} 2.1$ & 0,701 & 0,877 & 0,714 & 0,512 & 0,503 & 0,598 \\
\hline $\mathrm{X} 2.2$ & 0,577 & 0,709 & 0,418 & 0,39 & 0,41 & 0,443 \\
\hline $\mathrm{X} 2.3$ & 0,619 & 0,803 & 0,664 & 0,711 & 0,367 & 0,441 \\
\hline $\mathrm{X} 2.4$ & 0,651 & 0,838 & 0,639 & 0,48 & 0,448 & 0,537 \\
\hline $\mathrm{X} 3.1$ & 0,649 & 0,485 & 0,727 & 0,493 & 0,467 & 0,523 \\
\hline X3.2 & 0,772 & 0,673 & 0,854 & 0,715 & 0,587 & 0,571 \\
\hline $\mathrm{X} 3.3$ & 0,587 & 0,628 & 0,715 & 0,425 & 0,322 & 0,417 \\
\hline $\mathrm{X} 3.4$ & 0,564 & 0,55 & 0,768 & 0,485 & 0,525 & 0,509 \\
\hline $\mathrm{X} 3.5$ & 0,682 & 0,617 & 0,804 & 0,526 & 0,401 & 0,503 \\
\hline $\mathrm{X} 4.1$ & 0,563 & 0,561 & 0,548 & 0,846 & 0,527 & 0,494 \\
\hline $\mathrm{X} 4.2$ & 0,638 & 0,539 & 0,605 & 0,859 & 0,569 & 0,534 \\
\hline $\mathrm{X} 4.3$ & 0,613 & 0,539 & 0,634 & $\mathbf{0 , 8 1}$ & 0,602 & 0,55 \\
\hline $\mathrm{X} 4.4$ & 0,565 & 0,421 & 0,503 & 0,745 & 0,494 & 0,426 \\
\hline $\mathrm{X} 4.5$ & 0,594 & 0,554 & 0,538 & 0,844 & 0,441 & 0,559 \\
\hline Y1 & 0,709 & 0,604 & 0,545 & 0,534 & 0,614 & 0.785 \\
\hline Y2 & 0,628 & 0,521 & 0,569 & 0,453 & 0,595 & 0.767 \\
\hline Y3 & 0,639 & 0,57 & 0,532 & 0,503 & 0,767 & $\mathbf{0 , 8 1 7}$ \\
\hline Y4 & 0,471 & 0,313 & 0,348 & 0,408 & 0,609 & $\mathbf{0 , 7 2 8}$ \\
\hline Y5 & 0,733 & 0,449 & 0,566 & 0,558 & 0,641 & $\mathbf{0 , 8 3 6}$ \\
\hline $\mathrm{Z1}$ & 0,581 & 0,418 & 0,569 & 0,591 & 0,745 & 0,588 \\
\hline $\mathrm{Z3}$ & 0,626 & 0,587 & 0,587 & 0,626 & 0,815 & 0,676 \\
\hline $\mathrm{Z4}$ & 0,552 & 0,386 & 0,35 & 0,369 & 0,792 & 0,672 \\
\hline $\mathrm{Z5}$ & 0,482 & 0,313 & 0,407 & 0,459 & $\mathbf{0 , 8 1 2}$ & 0,66 \\
\hline
\end{tabular}

\section{Cronbach Alpha}

Uji reliabilitas dapat dilihat dari nilai Cronbach Alpha untuk setiap variabel. Standar nilai adalah $\geq 0,7$ untuk semua konstruk. Hasil uji reabilitas dengan melihat nilai Cronbach Alpha pada penelitian ini ditunjukkan pada tabel 12 .

Tabel 12. Cronbach Alpha

\begin{tabular}{|c|c|}
\hline Variabel & Cronbach's Alpha \\
\hline Kinerja & 0,847 \\
\hline Teknologi informasi & 0,731 \\
\hline Lingkungan kerja & 0,823 \\
\hline Motivasi kerja & 0,833 \\
\hline $\begin{array}{c}\text { Organizational Citizenship } \\
\text { Behavior }\end{array}$ & 0,879 \\
\hline Dukungan sosial & 0,801 \\
\hline
\end{tabular}

Berdasarkan nilai cronbach's alpha pada tabel 12, diketahui bahwa nilai yang diperoleh tiap variabel $\geq 0,70$. Dapat disimpulkan bahwa semua konstruk memiliki nilai cronbach's alpha yang baik karena telah memenuhi syarat.

\section{Analisis Statistik Inferensial}

Untuk pengujian hipotesis digunakan nilai probabilitas, nilai $p$-value dengan alpha 5\%. Nilai t-tabel untuk alpha 5\% dengan 61 responden adalah 1,96. Hasil bootstrapping menunjukkan besaran nilai $t$ dari setiap variabel independen terhadap variabel dependen. Adapun nilai Path Coefficient dapat dilihat dalam tabel berikut: 
Tabel 13. Analisis Statistik Inferensial

\begin{tabular}{|c|c|c|c|c|c|}
\hline Variabel & $\begin{array}{c}\text { Original } \\
\text { Sample } \\
(\mathrm{O})\end{array}$ & $\begin{array}{c}\text { Sample } \\
\text { Mean } \\
(\mathrm{M})\end{array}$ & $\begin{array}{l}\text { Standard } \\
\text { Deviation } \\
(\mathrm{STDEV})\end{array}$ & \begin{tabular}{|c}
$\mathrm{T}$ \\
statistik \\
$(\mathrm{O} / \mathrm{STD}$ \\
$\mathrm{EV})$ \\
\end{tabular} & P Value \\
\hline $\begin{array}{c}\text { Teknologi } \\
\text { informasi } \\
\text { (X1) -> } \\
\text { Kinerja (Y) }\end{array}$ & 0,580 & 0,561 & 0,160 & 3,812 & 0,000 \\
\hline $\begin{array}{c}\text { Lingkungan } \\
\text { kerja }(\mathrm{X} 2) \text { - } \\
>\text { Kinerja } \\
(\mathrm{Y})\end{array}$ & 0,140 & 0,131 & 0,097 & 1,400 & 0,162 \\
\hline $\begin{array}{c}\text { Motivasi } \\
\text { kerja }(\mathrm{X} 3) \text { - } \\
>\text { Kinerja } \\
(\mathrm{Y})\end{array}$ & $-0,270$ & $-0,254$ & 0,112 & 2,432 & 0,015 \\
\hline $\begin{array}{c}\text { Organizatio } \\
\text { nal } \\
\text { Citizenship } \\
\text { Behavior } \\
\text { (X4) -> } \\
\text { Kinerja (Y) }\end{array}$ & $-0,059$ & $-0,057$ & 0,094 & 0,641 & 0,522 \\
\hline $\begin{array}{c}\text { Moderasi } \\
\text { Teknologi } \\
\text { informasi } \\
\text { (X1) -> } \\
\text { Kinerja (Y) }\end{array}$ & $-0,598$ & $-0,555$ & 0,176 & 3,572 & 0,000 \\
\hline $\begin{array}{l}\text { Moderasi } \\
\text { Lingkungan } \\
\text { kerja }(\mathrm{X} 2) \text { - } \\
\text { > Kinerja } \\
\text { (Y) }\end{array}$ & 0,104 & 0,075 & 0,133 & 0,760 & 0,448 \\
\hline $\begin{array}{c}\text { Moderasi } \\
\text { Motivasi } \\
\text { kerja (X3) - } \\
>\text { Kinerja } \\
\text { (Y) }\end{array}$ & 0,263 & 0,261 & 0,115 & 2,287 & 0,023 \\
\hline $\begin{array}{c}\text { Moderasi } \\
\text { Organizatio } \\
\text { nal } \\
\text { Citizenship } \\
\text { Behavior } \\
\text { (X4) -> } \\
\text { Kinerja (Y) }\end{array}$ & 0,211 & 0,203 & 0,203 & 2,384 & 0,018 \\
\hline
\end{tabular}

Berdasarkan hasil uji pengaruh antar variabel seperti ditunjukkan tabel diatas, maka dapat dijelaskan sebagai berikut.

\section{Hipotesis 2: Pengaruh Teknologi Informasi (X1) terhadap Kinerja Pegawai (Y)}

Dari hasil uji hipotesis dua (2) diperoleh nilai t-statistik sebesar 3,812. Nilai ini lebih besar dari nilai t-tabel 1,96 dan nilai $P$ value 0,000 lebih kecil dari nilai alpha 0,05 . Artinya bahwa variabel teknologi informasi memiliki pengaruh yang signifikan terhadap kinerja pegawai. Maka hipotesis dua yang mengatakan bahwa teknologi informasi berpengaruh secara signifikan terhadap kinerja pegawai diterima.

\section{Hipotesis 3: Pengaruh Lingkungan Kerja (X2) terhadap Kinerja Pegawai (Y)}

Hasil uji hipotesis tiga (3) diperoleh nilai tstatistik sebesar 1,400 , nilai ini lebih kecil dari ttabel 1,96. Nilai $P$ value sebesar 0,162 lebih besar dari nilai alpha 0,05. Dengan demikian, kesimpulannya variabel lingkungan kerja tidak berpengaruh signifikan terhadap variabel kinerja pegawai. Dengan demikian, hipotesis ketiga ditolak.

\section{Hipotesis 4: Pengaruh Motivasi Kerja (X3) terhadap Kinerja Pegawai (Y)}

Hasil uji hipotesis empat (4) diperoleh nilai t-statistik sebesar 2,432, nilai tersebut lebih besar dari t-tabel 1,96. Nilai $P$ value 0,015 lebih kecil dari nilai alpha 0,05. Dengan demikian, dapat disimpulkan bahwa variabel motivasi kerja berpengaruh signifikan terhadap variabel kinerja pegawai. Artinya makin tinggi motivasi kerja maka kinerja pegawai akan makin meningkat. Dengan demikian, hipotesis keempat diterima.

\section{Hipotesis 5: Pengaruh Organizational Citizenship Behavior (X4) terhadap Kinerja Pegawai (Y)}

Hasil uji hipotesis lima (5) diperoleh nilai t-statistik sebesar 0,641 , perolehan nilai ini lebih kecil dari nilai t-tabel 1,96. Di samping itu, nilai $\mathrm{P}$ value 0,522 lebih besar dari nilai alpha 0,05 . Dengan demikian, dapat dijelaskan bahwa variabel Organizational Citizenship Behavior tidak berpengaruh signifikan terhadap variabel kinerja karyawan. Dengan demikian, hipotesis kelima ditolak.

Hipotesis 6: Dukungan Sosial (Z) Memoderasi Pengaruh Teknologi Informasi terhadap Kinerja Pegawai LPP TVRI Stasiun NTT

Hipotesis enam (6) yang menguji pengaruh teknologi informasi terhadap kinerja karyawan dengan pemoderasi dukungan sosial, menunjukkan bahwa efek moderasi 1 konstruk interaksi antara teknologi informasi (X1) (X1*Z1) dan dukungan sosial (Z1) mampu memoderasi pengaruh teknologi informasi terhadap kinerja pegawai dengan nilai t-statistik 3.572 lebih besar dari nilai t-table $1,96(3,572>1,96)$ dan nilai $\mathrm{p}$ value 0,000 $<$ (tingkat signifikansi 5\%), maka hipotesis ke 
enam yang mengatakan bahwa dukungan sosial mampu memoderasi pengaruh teknologi informasi terhadap kinerja pegawai diterima.

\section{Hipotesis 7: Dukungan Sosial (Z) Memoderasi Pengaruh Lingkungan Kerja terhadap Kinerja Pegawai LPP TVRI Stasiun NTT}

Hipotesis tujuh (7) menguji pengaruh lingkungan kerja terhadap kinerja karyawan dengan pemoderasi dukungan sosial, menunjukkan bahwa efek moderasi 2 (konstruk interaksi antara lingkungan kerja (X2) (X2*Z1) dan dukungan sosial (Z1) tidak mampu mempengaruhi kinerja pegawai. dengan nilai t-statistik 0,760 . Nilai ini lebih kecil dari nilai t-tabel $1,96(0,769<1,96)$ dan nilai $p$ value $0,448>0,05$, sehingga hipotesis 7 yang mengatakan bahwa dukungan social memoderasi pengaruh lingkungan kerja terhadap kinerja pegawai ditolak.

\section{Hipotesis 8: Dukungan Sosial (Z) Memoderasi Pengaruh Motivasi (X3) terhadap Kinerja Pegawai LPP TVRI Stasiun NTT}

Hipotesis delapan (8) menguji pengaruh motivasi (X3) terhadap kinerja karyawan (Y) dengan pemoderasi dukungan sosial (Z), menunjukkan bahwa efek moderasi 3 konstruk interaksi antara motivasi (X3) dan dukungan sosial (Z1) mampu mempengaruhi kinerja pegawai. Dengan kata lain dukungan sosial mampu memoderasi pengaruh $\mathrm{X} 3 \quad(\mathrm{X} 3 * \mathrm{Z} 1)$ terhadap kinerja pegawai dengan nilai t-statistik 2,287. Nilai perolehan lebih besar dari nilai t-tabel 1,96 $(2,287$ $>1,96)$ dan nilai $p$ value sebesar $0,023<0,05$. Oleh sebab itu, hipotesis 8 yang mengatakan bahwa dukungan sosial memoderasi pengaruh motivasi terhadap kinerja pegawai diterima.

Hipotesis 9: Dukungan Sosial (Z) Memoderasi Pengaruh Organizational Citizenship Behavior (X3) terhadap Kinerja Pegawai LPP TVRI Stasiun NTT

Hipotesis ke-9 yang menguji pengaruh organizational citizenship behavior (X4) terhadap kinerja karyawan (Y) dengan pemoderasi dukungan sosial (Z), menunjukkan bahwa efek moderasi 4 konstruk interaksi antara organizational citizenship behavior (X4) dan dukungan sosial (Z1) mampu mempengaruhi kinerja pegawai. Dengan kata lain dukungan sosial mampu memoderasi pengaruh $\mathrm{X} 4 \quad(\mathrm{X} 4 * \mathrm{Z} 1)$ terhadap kinerja pegawai dengan nilai t-statistik 2,384. Nilai ini lebih besar dari nilai t-tabel 1,96 $(2,287>1,96)$ dan nilai $p$ value $0,023<0,05$, sehingga hipotesis 9 yang mengatakan bahwa dukungan sosial memoderasi pengaruh motivasi terhadap kinerja pegawai diterima.

\section{Nilai $R$ Square $\left(\mathbf{R}^{2}\right)$}

Nilai $R$ Square $\left(\mathrm{R}^{2}\right)$ menunjukkan tingkat determinasi variabel bebas ke variabel terikat. Nilai $\mathrm{R}$ Square yang semakin besar menunjukkan tingkat determinasi yang semakin baik. Hasil perhitungan $\mathrm{R}$ Square pada penelitian ini dapat dilihat pada tabel berikut:

\begin{tabular}{|c|c|c|} 
Tabel 14. Nilai R Square \\
\begin{tabular}{|c|c|c|}
\hline & R Square & R Square Adjusted \\
\hline Kinerja & 0,548 & 0,516 \\
\hline Dukungan sosial & 0,865 & 0,842 \\
\hline
\end{tabular}
\end{tabular}

Berdasarkan nilai R Square pada tabel 14 diketahui bahwa nilai koefisien determinasi variabel dukungan sosial sebesar 0,865 dan koefisien determinasi variabel kinerja sebesar 0,548 . Nilai ini menerangkan bahwa kontribusi variabel variabel teknologi informasi, lingkungan kerja, motivasi, organizational citizenship behavior dan dukungan sosial terhadap variabel kinerja adalah sebesar 54.8\%. Sedangkan kontribusi variabel teknologi informasi, lingkungan kerja, motivasi dan organizational citizenship behavior terhadap dukungan sosial adalah sebesar $86.5 \%$.

\section{KESIMPULAN}

Berdasarkan hasil analisis yang telah dibahas, maka dapat disimpulkan sebagai berikut:

1. Teknologi informasi berpengaruh signifikan terhadap kinerja pegawai. Artinya apabila perkembangan teknologi informasi melalui indikator ketersediaan perangkat keras (Hardware) dan perangkat lunak (Software) serta manusia yang semakin baik dalam penguasaan teknologi informasi, maka akan dapat meningkatkan kinerja dari pegawai pada 
LPP TVRI Stasiun NTT.

2. Pengaruh lingkungan kerja terhadap kinerja pegawai tidak dapat diukur karena tingkat kesalahan yang diuji melebihi tingkat kesalahan yang ditoleransi. Artinya lingkungan kerja semakin bersih, dengan penerangan yang baik, dan dilengkapi dengan sarana dan prasarana yang lengkap, tidak memberikan pengaruh terhadap kinerja pegawai.

3. Motivasi kerja berpengaruh signifikan terhadap kinerja pegawai, artinya semakin tinggi motivasi pegawai yang ditunjukkan melalui keinginan untuk berprestasi, melakukan perbaikan dan perubahan, meningkatkan kemampuan kerja dan memperbaiki hubungan kerja, maka kinerja pegawai akan semakin meningkat.

4. Organizational citizenship behavior (OCB) berpengaruh tidak signifikan terhadap kinerja pegawai. Artinya walaupun OCB ditumbuhkan dalam perusahaan dalam bentuk pegawai saling membantu secara sukarela, bekerja melebihi standar yang ditetapkan, memelihara suasana kerja yang nyaman, menjaga hubungan baik dengan rekan kerja, dan setia terhadap organisasi, namun tidak akan mampu meningkatkan kinerja pegawai LPP TVRI Stasiun NTT.

5. Dukungan sosial dengan lima indikatornya yaitu dukungan emosi, dukungan penghargaan, dukungan instrumental dan konkrit, dukungan informasi dan dukungan jaringan sosial merupakan variabel moderasi karena dapat memoderasi pengaruh teknologi informasi terhadap kinerja pegawai LPP TVRI Stasiun NTT.

6. Dukungan sosial bukan merupakan variabel moderasi antara lingkungan kerja dan kinerja pegawai, sebab dukungan sosial memberikan pengaruh terhadap makhluk hidup sedangkan lingkungan kerja pada penelitian ini yaitu lingkungan fisik atau benda sehingga dukungan sosial tidak dapat memoderasi lingkungan fisik atau benda mati.

7. Dukungan sosial merupakan variabel moderasi, karena dapat memberikan dampak moderasi atau memperkuat pengaruh motivasi kerja terhadap kinerja pegawai LPP TVRI Stasiun NTT.

8. Dukungan sosial merupakan variabel moderasi, karena dapat memberikan dampak moderasi atau memperkuat pengaruh Organizational Citizenship Behavior terhadap kinerja pegawai LPP TVRI Stasiun NTT.

\section{DAFTAR PUSTAKA}

\section{Buku:}

Ahyari, Agus. (1999). Manajemen Produksi Perencanaan Sistem Produksi, edisi Ke 4, BPFE, Yogyakarta

Ariesto H. Sutopo. (2012). Teknologi Informasi dan Komunikasi dalam Pendidikan. Yogyakarta: Graha Ilmu

Bain, Read. (1937). Technology and State Government. Miami: American Sociological Association

Bernardin, H. John and Russel. (2010). Human Resource Management. New York: McGraw-Hill

Bohlander, George., and Snell, Scott. (2010). Principles of Human Resource. Management, 15th Ed. Mason, OH: South Western - Cengage Learning

Danim, S. (2008). Kinerja Staf dan Organisasi. Cetakan ke-10. Bandung: Pustaka Setia

Dessler, Gary. (2010). Manajemen Sumber Daya Manusia (edisi kesepuluh). Jakarta Barat: PT Indeks

Franklin, Ursula. (1989). Real World of Technology. House of Anansi Pres Mikro). Jakarta: Djambatan

Fuad, Noor, Gofur Ahmad. (2009). Integrated Human Resources Development berdasarkan Pendekatan CB-HRM, TB$H R M, C B T$, dan CPD. Jakarta: Grasindo.

Ghozali, Imam. (2012). Aplikasi Analisis Multivariate dengan Program IBM SPSS. Yogyakarta

Ghozali, Imam. (2016). Aplikasi Analisis Multivariete dengan Program IBM SPSS 23. Semarang: Badan Penerbit Universitas Diponegoro.

Haag, S., Keen, P. (1996). Information Technology, Tomorrow's Advantage Today. McGraw-Hill 
Hasibuan, M. (2012). Manajemen Sumber Daya Manusia Cetakan ke tiga belas. Jakarta: Bumi Aksara

Hasibuan, Malayu. (2015). Manajemen Sumber Daya Manusia, Edisi Revisi.: Bumi Aksara, Jakarta.

Hasibuan, Malayu S. P. (2007). Organisasi dan Motivasi Dasar Peningkatan Produktivitas. Jakarta: PT. Bumi Aksara

Jogiyanto, H.M. (2005). Analisa dan Desain Sistem Informasi: Pendekatan Terstruktur Teori dan Praktik Aplikasi Bisnis. Yogyakarta: ANDI

Kasmir. (2016). Manajemen Sumber Daya Manusia (Teori dan Praktik). Depok: PT. Rajagrafindo Persada

King, L. A. (2012). Psikologi Umum: Sebuah Pandangan Apresiatif Buku 2. Jakarta: Salemba Humanika

L. Mathis, Robert \& H. Jackson, John. (2009). Manajemen Sumber Daya Manusia. Jakarta:Salemba Empat.

L. Mathis, Robert \& H. Jackson, John. (2011). Human Resource Management (edisi 10). Jakarta: Salemba Empat

L. Mathis, Robert \& H. Jackson, John. (2013). Human Resource Management (edisi 14). Jakarta: Salemba Empat

Lucas, H. (2000). Information Technology for Management ( $7^{\text {th }}$ ed.) Irwin/McGraw-Hill

Luthans, Fred. (2006). Perilaku Organisasi. Edisi Sepuluh, PT. Andi: Yogyakarta

Mahsun, M. (2006). Pengukuran Kinerja Sektor Publik. Yogyakarta: BPFE Yogyakarta

Mangkunegara, A.A. Anwar Prabu. (2009). Manajemen Sumber Daya Manusia. Bandung: PT. Remaja Rosdakarya

Mangkunegara, A.A. Anwar (2010). Evaluasi Kinerja Sumber Daya Manusia. Bandung: PT. Refika Aditama

Martin, E. (1999). Managimg Information Technology What Managers Need to know ( $3^{\text {rd }}$ ed) New Jersey: Pearson Education International

Nitisemito, Alex S. (1998). Manajemen Personalia, Jakarta: Ghalia Indonesia

Nitisemito, Alek S. (2008). Manajemen Personalia, Edisi kedua. Jakarta: Ghalia Indonesia.
Noe, Raymond A., John R. Hollenbeck., Barry Gerhart and Patrick M. Wright. (2011). Fundamentals of Human Resource Management. New York: McGraw Hill

Prasetyo, Bambang \& Jannah, Miftahul. (2005). Metode Penelitian Kuantitatif Teori dan Aplikasi. Jakarta: Grafindo Persada

Prawirosentono, Suyadi. (1999). Manajemen Sumber Daya Manusia (Kebijakan Kinerja Karyawan), Kiat membangun Organisasi Kompetitif menjelang Perdagangan Bebas Dunia, Edisi Pertama. Yogyakarta: BPFE

Rivai. Veithzal. (2011). Manajemen Sumber Daya Manusia Untuk Perusahaan dari Teori ke Praktek. Jakarta: Grafindo

Robbins, P. Stephen. (2006). Perilaku Organisasi, Edisi Kesepuluh. Indonesia: Prentice Hall

Robbins, Stephen P \& Judge, Timothy A. (2013). Organizational Behavior Edition 15. New Jersey: Pearson Education

Samsudin, Sadili. (2010). Manajemen Sumber Daya Manusia. Bandung: Pustaka Setia

Sarafino, E.P., (2007). Health Psychology: Biopsychological Interaction. Kanada: John Wiley \& Sons, Inc

Sedarmayanti. (2009). Sumber Daya Manusia dan Produktivitas Kerja. Bandung: Mandar Maju

Sedarmayanti. (2011). Sumber Daya Manusia dan Produktivitas Kerja. Bandung: Mandar Maju

Sinambela, L. P. (2006). Reformasi Pelayanan Publik. Jakarta: Bumi Aksara

Siswanto, H.B. (2005). Pengantar Manajemen. Jakarta: PT. Bumi Aksara

Sugiyono (2011). Statistika Untuk Penelitian. Bandung: Alfabeta.

-- (2012). Metode Penelitian Pendekatan Kuantitatif, Kualitatif dan R\&D. Bandung: Alfabeta.

(2014). Metode Penelitian Pendidikan

Pendekatan Kuantitatif, Kualitatif, dan R\&D. Bandung: Alfabeta.

-- (2015). Metode Penelitian Pendidikan (Pendekatan kuantitatif, kualitatif, dan R\&D). Bandung: Alfabeta.

Sutarman. (2009). Pengantar Teknologi Informasi. Jakarta: Bumi Aksara. 
Taylor, Shelley E., Letitia Anne Peplau \& David O. Sears. (2009). Psikologi Sosial Edisi Kedua Belas. Jakarta: Kencana Prenada Media Group.

Thompson, Ronald L., Higgins, Christoper A. dan Howell, Jane M. (1991). Personal Computing: Toward a Conceptual Model of Utilization. MIS Quarterly

Veithzal Rivai, (2009), Manajemen Sumber Daya Manusia untuk Perusahaan dari Teori ke Praktik, edisi ke-2, Jakarta: Rajawali Pers

Wibowo. (2007). Manajemen Kinerja. Jakarta: Rajawali Pres.

Willian, Brian. \& Sawyer, Stacey. (2003). Using Infromation Technology A Practical Introduction To Komputers And Communications ( $7^{\text {th }}$ ed.). McGraw-Hill

Winardi, 2016. Motivasi dan Pemotivasian Dalam Manajemen. Jakarta. Raja Grafindo Perkasa

\section{Jurnal}

Agus Murdiyanto. (2012). Analisis pengaruh motivasi dan lingkungan kerja terhadap kinerja karyawan motor hepy cabang jawa tengah. Semarang: Falkultas Ekonomi Universitas Stikubank Semarang jurnal manajemen. Vol. 09, hal 12-28.

Aisyah, H. (2020). Pengaruh Kepuasan Kerja dan Komitmen Organisasi Terhadap Organizational Citizensship Behavior (OCB). Journal of Enterprise and Development, 2 (1), 17.

Alannita, Ni Putu., Suaryana, I. G. N. A. (2014). Pengaruh Kecanggihan Teknologi Informasi, Partisipasi Manajemen, Dan Kemampuan Teknik Pemakai Sistem Informasi Akuntansi Pada Kinerja Individu. Jurnal Akuntansi Universitas Udayana 6.1 (2014):33-45.

Aldag, R., \& Reschke, W. (1997). Employee value added: Measuring discretionary effort and its value to the organization. Center for Organization Effectiveness, 608, 8333332.

Aldo Herlambang Gardjito, Mochammad Al Musadieq, dan Gunawan Eko Nurtjahjono. (2014). Pengaruh Motivasi Kerja, dan Lingkungan Kerja Terhadap Kinerja
Karyawan (studi pada Karyawan Bagian Produksi PT. Karmand Mitra Andalan Surabaya). Jurnal Administrasi Bisnis (JAB) Vol. 13 No. 1 Agustus 2014

Apollo, \& Cahyadi, A. (2012). Konflik Peran Ganda Perempuan Menikah yang Bekerja Ditinjau dari Dukungan Sosial Keluarga dan Penyesuaian Diri. Widya Warta No. 02 Tahun XXXV I/ Juli 2012 ISSN 08541981, 261-262.

C. Ann Smith, et. al., (1983), "Organizational Citizenship Behavior: Its Nature and Antecedents", Journal of Applied Psychology, Vol. 68, No. 4, 1983, pp. 653663

Cahyani, Welsya., (2019). "Peran Dukungan Sosial Terhadap Stres Kerja Sebagai Peningkatan Kinerja Karyawan", Jurnal Ilmu Manajemen Volume 7 Nomor 3 - Jurusan Manajemen Fakultas Ekonomi Universitas Negeri Surabaya

Damanik, Eva Setiarini. (2017). Pengaruh Sistem Akuntansi Keuangan, Teknologi Informasi Dan Komitmen Organisasi Terhadap Kinerja Satuan Kerja Perangkat Daerah (SKPD) Di Lingkungan Pemerintah Kabupaten Tebo. Ekonomi: Jurnal of Economics and Business Vol.1 No.1

Dhermawan, Anak Agung Ngurah Bagus., Sudibya, I Gde Adnyana., Utama, I Wayan Mudiartha. (2012). Pengaruh Motivasi, Lingkungan Kerja, Kompetensi, Dan Kompensasi Terhadap Kepuasan Kerja Dan Kinerja Pegawai Di Lingkungan Kantor Dinas Pekerjaan Umum Provinsi Bali. Jurnal Manajemen, Strategi Bisnis, dan Kewirausahaan Vol. 6, No. 2.

Farid, H. T., Hamid, D., \& Nurtjahjono, G. E. (2016). Pengaruh motivasi kerja terhadap kedisiplinan dan kinerja pegawai PT. PLN distribusi Jawa Timur area Malang. Jurnal Administrasi Bisnis, 32(1), 75-81.

Farizki, Muchamad, Ressa., Wahyuati Aniek. (2017). Pengaruh Motivasi Kerja dan Lingkungan Kerja Terhadap Kinerja Karyawan Medis. Jurnal Ilmu dan Riset Manajemen. 6 (5). 
Ferawati, Apfia. (2017). Pengaruh Lingkungan Kerja Dan Disiplin Kerja Terhadap Kinerja Karyawan. AGORA Vol. 5, No.1.

Hanafi, B. D., \& Yohana, C. (2017). Pengaruh Motivasi, Dan Lingkungan Kerja, Terhadap Kinerja Karyawan, Dengan Kepuasan Kerja Sebagai Variabel Mediasi Pada Pt Bni Lifeinsurance. Jurnal Pendidikan Ekonomi Dan Bisnis (JPEB), 5(1), 72.

Handayani, Ratina., Runtuwene, Roy F., Sofia A.P, Sambul. (2018). Pengaruh Penguasaan Teknologi Informasi Terhadap Kinerja Karyawan Pada PT. Telkom Indonesia Cabang Manado. Jurnal Administrasi Bisnis Vol. 6 No. 2 Tahun 2018.

Hidayat, Zainul., Taufiq, Muchamad. (2012). Pengaruh Lingkungan Kerja dan Disiplin Kerja serta Motivasi Kerja Terhadap Kinerja Karyawan Perusahaan Daerah Air Minum (PDAM) Kabupaten Lumajang. Jurnal WIGA Vol. 2 No. 1, ISSN NO 20880944.

Isnawati, D., \& Suhariadi, F. (2013). Hubungan Antara Dukungan Sosial dengan Penyesuaian Diri Masa Persiapan Pensiun pada Karyawan PT Pupuk Kaltim. Jurnal Psikologi Industri dan Organisasi, 02, (1)

Kasim, Dhesty., Rantetampang, A.L., dan Lumbantobing, Happy. (2016). Relationships of Work Discipline, Leadership, Training, and Motivation to Performance of Employees Administration Abepura Hospital Papua. International Journal of Sciences: Basic and Applied Research (IJSBAR) (2016) Volume 26, No 1, pp 154-164 ISSN 23074531.

Lambert, E. G., Minor, K. I., Wells, J. B., \& Hogan, N. L. (2016). Sosial support's Relationship to correctional staff job Stress, job involvement, job satisfaction, And organizational commitment. Sosial Science Journal, 53(1), 22-32.

Lomban, M. C., Mandey, S., \& Walangitan, M. D. (2015). Pengaruh Motivasi, Upah dan Disiplin Kerja Terhadap Kinerja Pegawai Di Kantor Catatan Sipil Manado. Jurnal
EMBA: Jurnal Riset Ekonomi, Manajemen, Bisnis dan Akuntansi, 3(1).

Maflikhah, Nur. (2010). Peran Teknologi Informasi Pada Niat Untuk Mendorong Kwoledge Sharing Karyawan Sekretariat Daerah Pemerintah Kota Surakarta (Sebuah Pengujian Terhadap Teori Difusi Inovasi). Jurnal Ekonomi Universitas Sebelas Maret. Surakarta

Nahrisah, E., \& Imelda, S. (2019). Dimensi Organizational Citizenship Behavior (OCB) Dalam Kinerja Organisasi. Jurnal Ilmiah Kohesi, 3 (3), 40-41

Nasir, Azwir., Oktari, Ranti., (2011). Pengaruh Pemanfaatan Teknologi Informasi Dan Pengendalian Intern Terhadap Kinerja Instansi Pemerintah (Studi Pada Satuan Kerja Perangkat Daerah Kabupaten Kampar). Jurnal Akuntansi Fakultas Ekonomi Universitas Riau.

Nuryasin, I., Al Musadieq, M., \& Ruhana, I. (2016). Pengaruh Lingkungan Kerja Dan Motivasi Kerja Terhadap Kinerja Karyawan (Studi Pada Karyawan Perusahaan Daerah Air Minum (PDAM) Kota Malang). Jurnal Administrasi Bisnis, 41(1), 16-24.

Organ, D. W., \& Paine, J. B. (1999). A new kind of performance for industrial and organizational psychology: Recent contributions to the study of organizational citizenship behavior.

P. Edi Sumantri, (2016). Pengaruh Motivasi Kerja Dan Lingkungan Kerja Terhadap Kinerja Karyawan Pada Usaha Penjualan Mobil Bekas di Kecamatan Purwokerto Selatan Kabupaten Banyumas, Jurnal Pro Bisnis Vol 9 No. 2 Agustus 20161 ISSN : 1979 9268 e-ISSN : $2442-4536$

Paputungan, Faradistia R. (2013). Motivasi, Jenjang Karir Dan Disiplin Kerja Pengaruhnya Terhadap Kinerja Karyawan Pada Pt. Bank Sulut Cabang Calaca. Jurnal EMBA 679 Vol.1 No.4 Desember 2013, Hal. 679-688 ISSN 2303-1174

Purnama. C. (2013). Influence Analysis of Organizational Culture Organizational Commitment Job and Satisfaction 
Organizational Citizenship Behavior (OCB) Toward Improved Organizational Performance, International Journal of Business, Humanities and Technology, Vol. 3 No. 5; hal. 12-35.

Ramadhani, Fitri Ayu. (2019). Pengaruh

Dukungan Sosial Dan Gaya

Kepemimpinan Partisipatif Terhadap Kinerja Karyawan Pada Divisi Pemasaran Pdam Surya Sembada Kota Surabaya. Jurnal Ilmu Manajemen Volume 7 Nomor 2.

Sari, Mareta Kemala \& Hajriani, Ika. (2015). Pengaruh Karakteristik Budaya Organisasi Terhadap Organizational Citizenship Behavior (Studi Kasus Rumah Sakit Umum Citra Bunda Medical Centre Padang). Journal of EconomicEconomic And Economic Education, 3(2): 228 - 236. Setyowati, T., \& Nurhidayati, A. (2015). Pengaruh Stres Kerja terhadap Kinerja Dengan Dukungan Sosial sebagai Variabel Moderasi (Studi Kasus Tim Penggerak PKK Kabupaten Rembang). Potensio Jurnal STIE YPPI, 17(1), 1-10.

Siahaan, Syalimono., Bahri, Syaiful. (2019). Pengaruh Penempatan Pegawai, Motivasi, Dan Lingkungan Kerja Terhadap Kinerja Pegawai. Maneggio: Jurnal Ilmiah Magister Manajemen Vol 2, No. 1, ISSN 2623-2634.

Suharto dan Budi Cahyono. (2005). Pengaruh Budaya Organisasi, Kepemimpinan dan Motivasi Kerja Terhadap Kinerja Sumber Daya Manusia, di sekretariat DPRD Propinsi Jawa Tengah. JRBI. Vol. 1, No.1, januari 2005: 13-30.

Surjosuseno, Daniel. (2015). Pengaruh

Lingkungan Kerja Dan Motivasi Kerja Terhadap Kinerja Karyawan Pada Bagian Produksi Ud Pabrik Ada Plastic. AGORA Vol. 3, No. 2.

Turang, Richard Christian., Kindangen, Paulus., Tumiwa, Johan. (2015). Pengaruh Gaya Kepemimpinan, Motivasi, Dan Disiplin Kerja Terhadap Kinerja Karyawan Di Pt. Dayana Cipta. Jurnal Berkala Ilmiah Efisiensi Volume 15 No. 04. 